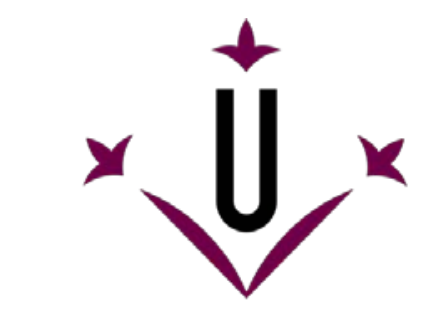

Universitat de Lleida

Document downloaded from:

http://hdl.handle.net/10459.1/65581

The final publication is available at:

https://doi.org/10.1111/asj.12728

Copyright

(c) Japanese Society of Animal Science, 2016 


\title{
Effect of castration at 10 months of age on growth physiology and behavior of male feral beef cattle
}

\author{
Javier ÁlVAREZ-ROdRÍGUEZ, ${ }^{2}$ Pere ALBERTí, ${ }^{1}$ Guillermo RIPOLL, ${ }^{1}$ Isabel BLASCO ${ }^{1}$ and Albina SANZ ${ }^{1}$ \\ ${ }^{1}$ Centro de Investigación y Tecnología Agroalimentaria (CITA), Instituto Agroalimentario de Aragón - IA2 (CITA- \\ Unizar), Zaragoza, ${ }^{2}$ Departament de Ciència Animal, Universitat de Lleida, Lleida, Spain
}

\begin{abstract}
This study compared the growth performance, plasma testosterone and cortisol levels around castration at 10 months of age, and plasma insulin-like growth factor (IGF)-I concentration and flight speed, in intact bulls and steers from 10 to 21 months of age in a feral Spanish breed. Fourteen bulls ( $366.5 \pm 48.5 \mathrm{~kg}$ live weight) were assigned at random to one of two treatments: surgically castrated (steers) or intact (bulls), and submitted to an identical fattening period. Steers reared until heavy live weights (21 months of age) grew slowly and had lower plasma IGF-I concentrations than intact bulls. These differences were mainly highlighted the month after surgery (11 months of age) and the last part of the fattening period (from 19 to 21 months of age). After surgical castration (11 and 12 months of age), steers showed a tendency to display greater flight speed values than intact bulls but baseline plasma cortisol concentration did not differ between groups at this time. At the end, steers and bulls reached nearly similar temperament, as flight speed did not differ between them. The results confirm the role of IGF-I as a key anabolic hormone in male beef cattle and thus it may reflect growth differences due to altered sex steroids production.
\end{abstract}

Key words: bull, cortisol, flight speed test, IGF-I, steer.

\section{INTRODUCTION}

In some production systems, growing calves are castrated to ease handling as well as to reduce sexual and aggressive behavior during the finishing phase. Castration alters growth rate and body composition in cattle due to a change in hormonal status (Henricks et al. 1988). The description of underlying mechanisms mediating the hormonal status in growing bulls compared to castrated calves usually comes from American literature where anabolic implants are used (Lee et al. 1990; Hunt et al. 1991; Schoonmaker et al. 2002). Thereby, the interactions between endogenous and exogenous effects of estrogenic hormones do not allow a detailed comparison with some animal husbandry systems that ban the use of growth promotants during fattening (i.e. European Union).

Some studies have proposed to delay castration until puberty ( 8 to 13 months of age, depending on the breed) to maintain the growth performance advantages of intact males until puberty and to obtain the benefits of castration on meat quality characteristics thereafter (Knight et al. 1999). Early maturing cattle breeds, such as Holstein, may be castrated before puberty and therefore slaughtered at younger ages (less than 12 months old) without detrimental effects on meat marbling. However, production parameters may be impaired.
Lipid deposition features in dairy breeds may differ from unselected feral breeds and/or late maturing beef breeds that can be slaughtered at older ages (around 20-24 months of age). In this regard, insulin-like growth factor-I (IGF-I) is considered a short-term indicator of the animal nutritional status (Ellenberger et al. 1989), as well as a mediator of the growth response to endogenous estrogens and androgens (Lee et al. 1990).

Cattle temperament is the behavioral response to stressful events, such as handling by humans. Flight speed has been suggested as a consistent measure of temperament (Burrow et al. 1988), and this trait has been related to growth performance in beef calves (Hoppe et al. 2010).

The aim of this study was to compare the growth performance, plasma testosterone and cortisol levels around castration at 10 months of age, as well as plasma IGF-I concentration and temperament in intact bulls and steers from a feral beef breed (Serrana de Teruel) from 10 to 21 months of age.

Correspondence: Javier Álvarez-Rodríguez, Departament de Ciència Animal, Universitat de Lleida, Lleida 25198, Spain.

Email: jalvarez@ca.udl.cat

Received 21 March 2016; accepted for publication 7 September 2016. 


\section{MATERIAL AND METHODS Animal management and experimental design}

This experiment was conducted at the facilities of the CITA Research Institute at Zaragoza $\left(41^{\circ} 42^{\prime} \mathrm{N}, 0^{\circ} 49^{\prime}\right.$ W, $216 \mathrm{~m}$ asl, Ebro Valley, Northeastern Spain). All procedures were approved by the in-house Ethics Committee for Animal Experiments at the CITA of Aragon. The care and use of animals were in accordance with the Spanish Policy for Animal Protection RD53/2013, which meets the European Union Directive 2010/63 on the protection of animals used for experimental and other scientific purposes.

Fourteen male calves from Serrana de Teruel breed were raised together from weaning at 4 months of age to 10 months of age. These cattle belonged to a dark or tabby-coated unselected breed which is seldom used to handling and it is raised in mountain areas of the center of Spain. During this earlier part of the growing period, all calves were fed concentrate plus straw ad libitum. Afterwards, young bulls ( $284 \pm 25$ days of age and $366.5 \pm$ $48.5 \mathrm{~kg}$ live weight ( $\mathrm{LW})$, mean \pm standard deviation) were assigned at random to one of two treatments: surgically castrated (steers) or intact (bulls). Castration was carried out using local anesthesia and analgesia with xylazine $(5 \mathrm{~mL}$ Rompún®; Bayer, Leverkusen, Germany) and ketamine (5 mL Imalgene ®; Mérial, Lyon, France), respectively. The fattening period was identical in both groups and it was divided into three

T1 feeding phases (Table 1).

\section{Productive measurements}

Feed intake (concentrate and barley silage) was registered daily on a group basis. Feed dry matter (DM) was determined at $60^{\circ} \mathrm{C}$ in a forced-oven until constant weight. Individual LW was recorded at weekly intervals during the fattening period and average daily gains (ADG) were estimated on a monthly basis by linear regression of LW against time.

\section{Blood sampling and analyses}

Blood samples $(5 \mathrm{~mL})$ were collected at monthly intervals by tail vessel puncture into vacuum heparinized tubes. Samples were centrifuged at $2500 \times g$ for $15 \mathrm{~min}$ at $4^{\circ} \mathrm{C}$. Plasma aliquots were prepared and stored at $-20^{\circ} \mathrm{C}$ until analysis.
Peripheral testosterone and cortisol were analyzed at 10 months (pre-castration) and 11 months of age (post-castration) whereas IGF-I concentration was analyzed on a monthly basis from 10 to 21 months old. All hormones were analyzed through solid-phase enzyme-labelled chemiluminiscent immunometric assays (Immulite $®$, Siemens Medical Solutions Diagnostics Limited, Llanberis, Gwynedd, UK). In case of plasma IGF-I, bovine samples previously analyzed through a commercial enzyme immunoassay kit (Blanco et al. 2010) were re-assayed to evaluate the accuracy of the analysis. A regression analysis was performed to compare the results obtained with both methods $(r=0.96)$. The mean intra- and inter-assay coefficients of variance $(\mathrm{CV})$ were $3.1 \%$ and $12.0 \%$, respectively.

\section{Flight speed test}

A flight speed test of individual calves was determined by the method of Burrow et al. (1988) at 9, 10, 11, 12 and 20 months of age. This test imposed conditions of close human contact, social isolation and physical restraint on the calf. All animals were previously exposed to experimental conditions, which included a weighing scale, while undergoing common cattle management handling routines. Measurements were taken between 09.00 and 11.00 hours. Calves were moved as a group from their pen to the chute in a calm manner by the same experienced stock people each time, who were wearing working clothes. Immediately after the entry into the chute, the calves were identified from their ear tag and the order of entry to the chute was noted. Calves stayed in the weighing scale for $30 \mathrm{~s}$ until an unknown person for the calves opened the chute. The calves proceeded at their own pace along a single straight alley without seeing other calves. Flight time was the time, measured with a stopwatch by the same person, taken by a calf from the opening of the weighing scale until the two front extremities crossed $5 \mathrm{~m}$. Flight speed was expressed in $\mathrm{m} / \mathrm{s}$.

\section{Statistical analyses}

Data were analyzed using the SAS statistical software (SAS Institute Inc., Cary, NC, USA). DM intake was analyzed with a general linear model (GLM procedure) considering gender and feeding phase as fixed effects. LW at the start of each feeding phase was analysed

Table 1 Feeding plan during the fattening period of steers and bulls from 10 to 21 months of age

\begin{tabular}{|c|c|c|c|}
\hline Age, months & $10-13$ & $14-18$ & $19-21$ \\
\hline Phase & I & II & III \\
\hline Months of the year & February-May & June-October & November-January \\
\hline Feed & $\begin{array}{l}\text { Concentrate }{ }^{+} \text {plus straw } \\
\text { ad libitum }\end{array}$ & $\begin{array}{l}3 \mathrm{~kg} / \text { day of concentrate plus } \\
\text { barley silage }^{\ddagger} \text { ad libitum }\end{array}$ & $\begin{array}{l}\text { Concentrate plus straw } \\
\text { ad libitum }\end{array}$ \\
\hline
\end{tabular}

\footnotetext{
${ }^{\dagger}$ Concentrate contained $93.0 \%$ dry matter (DM), $11.7 \mathrm{~kg} \mathrm{MJ}$ metabolizable energy (ME) $/ \mathrm{kg} \mathrm{DM}, 13.7 \%$ Crude protein $(\mathrm{CP}) .{ }^{\ddagger}$ Barley silage contained
} $37.9 \% \mathrm{DM}, 9.5 \mathrm{MJ} \mathrm{ME} / \mathrm{kg} \mathrm{DM}, 8.0 \% \mathrm{CP}$. 
with a GLM procedure considering gender as a fixed effect and age at castration as a covariate. LW throughout the fattening period, ADG, plasma testosterone, cortisol and IGF-I levels were analyzed with repeated measures mixed linear model (MIXED procedure) considering gender and age period as fixed effects and the animal as a random effect. Data are reported as least square means and their associated standard errors. Multiple comparisons were performed by Tukey's method. The level of significance was set at 0.05 , while tendencies were declared at levels between 0.05 and 0.10 .

Spearman's rank correlation coefficients were used to evaluate the relationships between the order of entry into the chute when flight speed was measured, and to identify the consistency of temperament between months of test. In addition, Spearman's rank correlation coefficients were calculated for the association between order of entry and ADG, and flight speed and ADG at each age period.

\section{RESULTS Productive parameters}

DM intake along the fattening period did not differ between steers and bulls (overall, 7.95 and $8.04 \pm 0.45 \mathrm{~kg}$ $\mathrm{DM} /$ day, respectively; $P>0.10$ ), but it was greater during the feeding phase I than during the feeding phase III on a metabolic LW basis $(79,75$ and $64 \pm 4 \mathrm{~g} \mathrm{DM} / \mathrm{kg}$ $\mathrm{LW}^{0.75} /$ day, in phase I, II and III, respectively; $P<$ 0.001 ). The data of feed intake for steers and bulls at

T2 each period (I, II and III) are reported in Table 2. Animal LW prior to castration (10 months of age) did not differ between groups $(367 \pm 17 \mathrm{~kg}, P>0.10)$, as it did not differ at the end of feeding phase I ( or start of feeding phase II) (14 months of age) $(487 \pm 17 \mathrm{~kg}, P>0.10)$. However, LW at the end of feeding phase II (or start of feeding phase III) (19 months of age) was already lower in steers than in bulls ( 552 vs. $623 \pm 17 \mathrm{~kg}, P<0.05$ ), as it did at slaughter ( 21 months of age) $(648$ vs. $743 \pm 20 \mathrm{~kg}, P<$ $0.01)$. Therefore, the mean ADG from 10 to 21 months of age was lower in steers than in bulls (0.99 vs. $1.23 \pm$ $0.05 \mathrm{~kg} /$ day, $P<0.001$ ), mainly due to the differences in the month following castration and the last fattening

F1 month (Fig. 1).

\section{Peripheral testosterone and cortisol around castration}

Plasma testosterone did not differ between gender groups at 10 months of age but, as expected, it was nearly undetectable in steers compared to bulls at 11 months of age (post-castration) $(P<0.001)$ (Fig. 2). F2 Plasma testosterone increased in intact bulls from 10 to 11 months of age $(P<0.05)$. Nevertheless, plasma cortisol did not differ between steers and bulls at 10 and 11 months of age $(P>0.10)$ (Fig. 2).

\section{Peripheral IGF-I}

Plasma IGF concentration did not differ between steers and bulls at the start of the fattening period (phases I and II) $(P>0.10)$, and only some tendencies for lower plasma IGF-I concentration in steers than in intact bulls was found at 12 and 16 months of age $(P<0.07)$ (Fig. 3). F3 Nevertheless, the differences between genders were strengthened during the last feeding period (phase III). Thereby, the mean plasma IGF-I concentration during the fattening period became lower in steers than in bulls (139 vs. $192 \pm 17 \mathrm{ng} / \mathrm{mL}, P<0.05$ ).

\section{Flight speed test}

There were no differences in flight speed tests between groups throughout the fattening period $(P<0.05)$ but there was a tendency for greater flight speed in steers than in bulls at $11(P=0.07)$ and 12 months of age $(P$ $=0.08$ ). However, flight speed results did not differ between groups at the end of the fattening period (20 months of age) $(P>0.10)$ (Fig. 4). The overall flight $\mathbf{F} 4$ speed of calves decreased throughout the fattening period $(P<0.05)$. Accordingly, there was a negative correlation between speed values and age period both in steers $\left(\mathrm{r}_{\mathrm{s}}=-0.47, P<0.01\right)$ and bulls $\left(\mathrm{r}_{\mathrm{s}}=-0.70, P<\right.$ $0.001)$.

No significant correlations were observed between order of entry in the chute and speed values at each session, either in steers $(P=0.28)$ or in bulls $(P=0.80)$. Similarly, no significant correlations was observed between order of entry in the chute and age period, either in steers $(P=0.22)$ or in bulls $(P=0.09)$. There was no correlation between order of entry and ADG, either in steers $(P=0.92)$ or in bulls $(P=0.67)$. In the same sense, there was no correlation between flight speed values

Table 2 Dry matter (DM) intake in steers and bulls at each feeding period from 10 to 21 months of age

\begin{tabular}{|c|c|c|c|c|c|c|}
\hline \multirow[b]{2}{*}{ Phase $^{\dagger}$} & \multicolumn{2}{|c|}{$\begin{array}{l}\text { Feed intake } \\
\text { (kg DM/day) }\end{array}$} & \multirow[t]{2}{*}{$\begin{array}{l}\text { Standard } \\
\text { error }\end{array}$} & \multicolumn{2}{|c|}{$\begin{array}{l}\text { Metabolic feed intake } \\
\text { (g DM/ kg LW }{ }^{0.75} / \text { day) }\end{array}$} & \multirow[t]{2}{*}{$\begin{array}{c}\text { Standard } \\
\text { error }\end{array}$} \\
\hline & Steers & Bulls & & Steers & Bulls & \\
\hline I & 7.57 & 7.52 & 0.83 & 81 & 78 & 7 \\
\hline II & 8.27 & 8.43 & 0.65 & 76 & 74 & 6 \\
\hline III & 10.71 & 10.85 & 0.83 & 88 & 84 & 7 \\
\hline
\end{tabular}

${ }^{\dagger} \mathrm{I}=$ concentrate feed ad libitum (10-13 months of age), II = barley silage ad libitum and $3 \mathrm{~kg}$ of concentrate supplement (14-18 months of age), III = concentrate feed ad libitum (19-21 months of age). LW, live weight. 

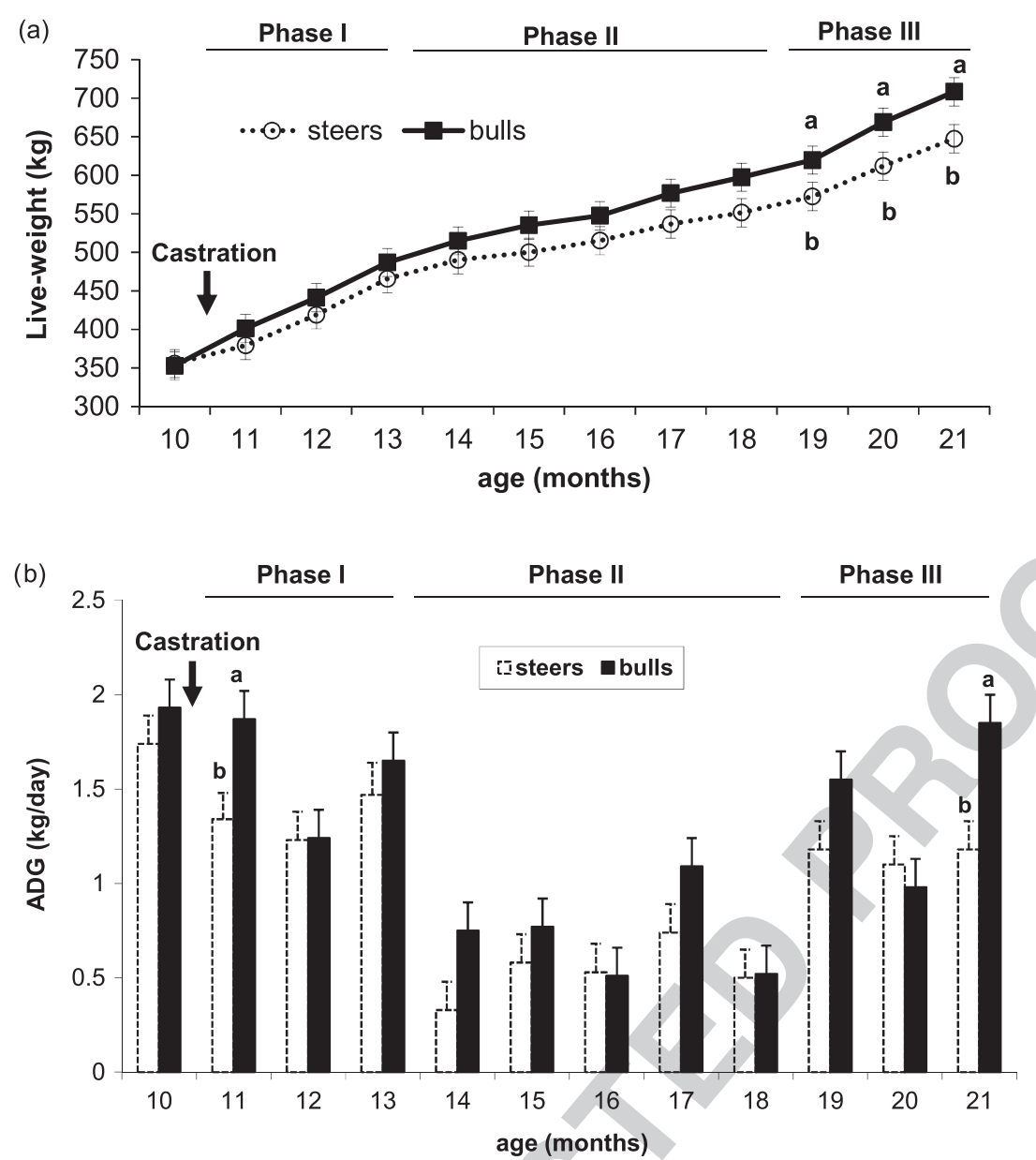

Figure 1 Live weight evolution (A) and monthly average daily gains (ADG) (B) in steers and bulls from 10 to 21 months of age (least square means \pm standard error)

and ADG in steers $(P=0.64)$ and only a slight association was found in bulls $\left(\mathrm{r}_{\mathrm{s}}=0.35, P=0.07\right)$.

\section{DISCUSSION}

Generally, it is assumed that steers grow slowly and deposit more fat than bulls (Lee et al. 1990). However, this assumption may be conditioned by the age at castration. The lower ADG in steers compared to intact bulls, especially during the month after castration, is in line with the results observed by Marti et al. $(2010,2013)$ in Holstein calves castrated at 3 or 8 months old and fed a similar concentrate-based diet. However, the ADG reduction was less marked when steers had been castrated at 5.5 months old (Pang et al. 2006), 7-9 months old (Cohen et al. 1990) or 13 months old (Ting et al. 2003) but fed forage-based diets (either good quality hay or grass silage supplemented with concentrate). Therefore, the difference in productive parameters between steers and bulls may be attenuated by forage compared to concentrate-based dietary strategies. Assuming that feed intake is controlled by physiological mechanisms and thereby it is linked to energy requirements
(Decruyenaere et al. 2009), forage diets could be applied more efficiently during the earlier fattening period (1018 months of age) since herein feed intake on a metabolic basis was greater in phases I and II than in phase III, even though during the last feeding period the animals were fed a concentrate-based diet.

In another close Spanish beef genotype (Parda de Montaña) castrated at 7-8 months of age and slaughtered at 18-19 months old (500 kg LW), the reduction in the productive performance of steers was modulated by supplementing with concentrate during the intermediate phase of the fattening period (concomitantly to the reduced forage availability season) instead of feeding a purely forage-based diet (Blanco et al. 2012), or by increasing the feeding level during the last fattening months (Blanco et al. 2014). In this study, ad libitum concentrate feeding in the last feeding period (phase III) did not counterbalance the lower ADG in steers compared to bulls.

In the current experiment, the ADG of intact bulls was kept within the range for other Spanish hardy genotypes (i.e. Asturiana de los Valles, Avileña) $(1.30-1.34 \mathrm{~kg} /$ day $)$ reared until 15 months of age 

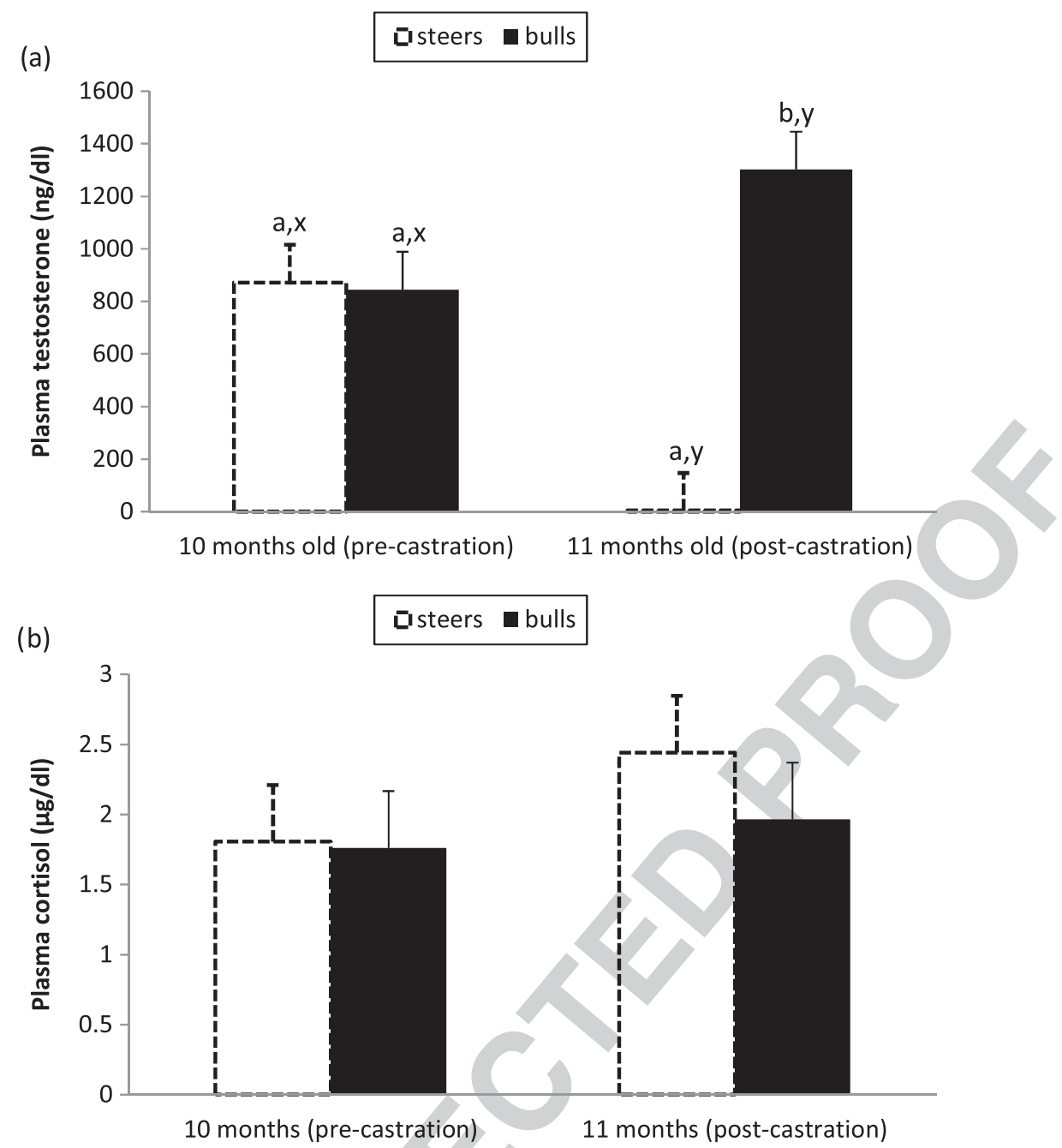

Figure 2 Circulating testosterone (A) and cortisol (B) in steers and bulls at 10 months (pre-castration) and 11 months of age (postcastration) (least square means \pm standard error). ${ }^{a, b}$ Denote statistical differences (at least $P<0.05$ ) between gender groups within each age period. ${ }^{x, y}$ Denote statistical differences (at least $P<0.05$ ) between age periods within each gender group

(550-560 kg LW) and fed a concentrate-based diet (Albertí et al. 2008). The present intact bulls reached a final LW of approximately $700 \mathrm{~kg}$, even though they were previously fed a forage-based diet during 5 months (from 14 to 18 months old). Considering that mature male LW in this breed is around $840 \mathrm{~kg}$ (FAO 2010), the recorded bull LW during the last feeding period (phase III) (19-21 months of age) represented around $80-85 \%$ of their mature LW. Meat quality parameters from these animals are reported elsewhere (Ripoll et al. 2016). Briefly, the bulls showed lower fatness degree but greater conformation score and dressing percentage than steers. Accordingly, the intramuscular fat content was lower, whereas the edible meat content was greater in bulls than in steers. The age at castration may have played a role in the observed body growth and fat deposition pattern. Although delayed castration (9 to 12 months old) has been suggested in late maturing beef breeds to allow intact bulls growing at greater rates than steers until puberty (Knight et al. 1999), this practice is conditioned by the interval to the target slaughter age/weight, which may not be increased due to excessive feeding costs. Bretschneider (2005) reviewed this issue and concluded that surgical castration performed after puberty has an important detrimental effect on growth performance, which extends for a period beyond the first 30 days post-castration. The hypothalamic-pituitary-adrenal axis is activated by surgical castration and triggers a short-term acute increase (3-6 h) in plasma cortisol concentration that rapidly declines the day after castration (Cohen et al. 1990; Stafford et al. 2002). In this study, we measured only basal plasma cortisol the previous day (10 months of age) and four weeks after castration (at 11 months of age). At this moment, no differences between groups were observed, indicating that the release of this adrenal corticosteroid returned to baseline and chronic stress was no longer present. 


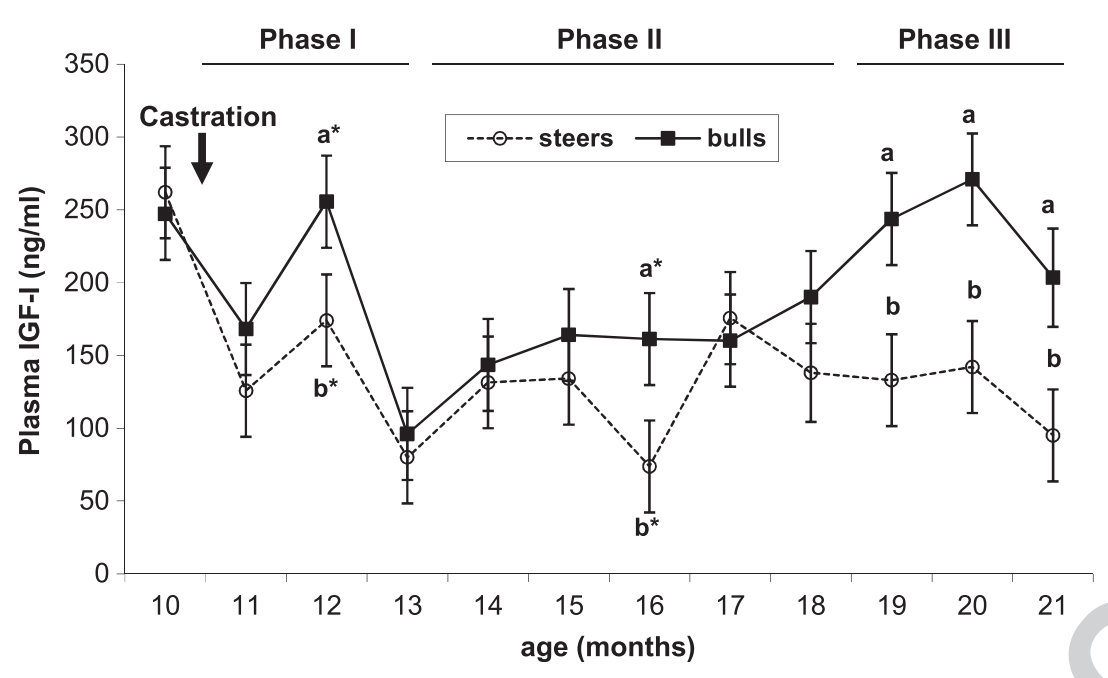

Figure 3 Plasma insulin-like growth factor-I (IGF-I) concentration in steers and bulls from 10 to 21 months of age (least square means \pm standard error). Different letters $\left({ }^{a, b}\right)$ denote statistical differences (at least $P<0.05$ ) between gender groups at monthly age periods. Different letters with asterisks $\left({ }^{a^{*}, b^{*}}\right)$ denote a tendency for statistical differences $(P<0.07)$ between gender groups at monthly age periods.

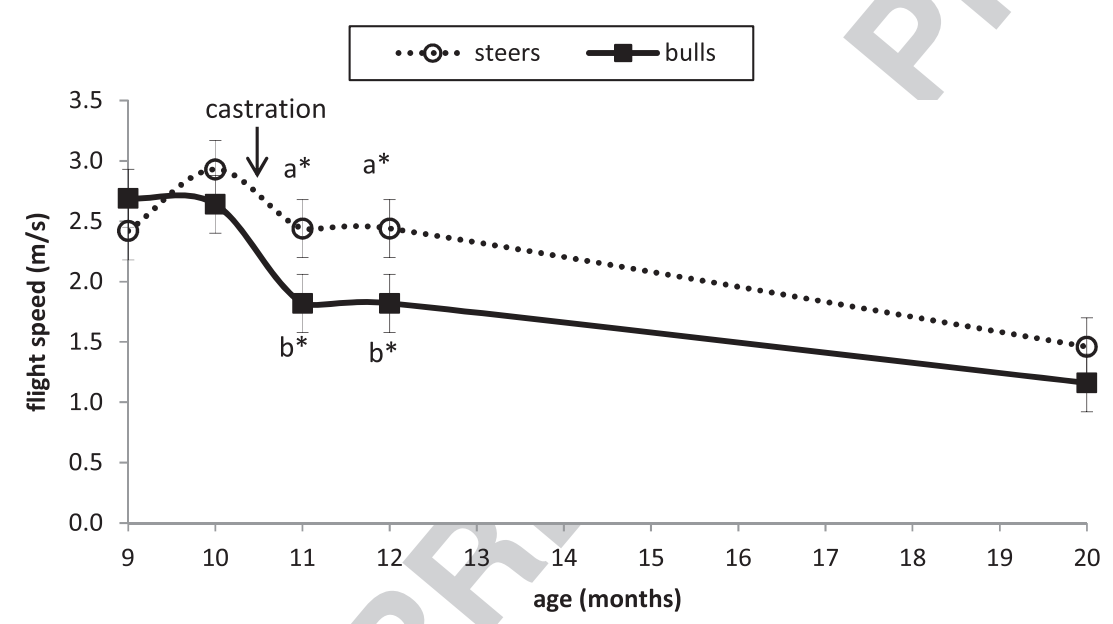

Figure 4 Flight speed test results in steers and bulls at 9, 10, 11, 12 and 20 months of age (least square means \pm standard error). Different letters with asterisks $\left({ }^{*}, b^{*}\right)$ denote a tendency for statistical differences $(P<0.08)$ between gender groups at monthly age periods.

According to Govoni et al. (2003), IGF-I hormone plays an important role in regulating metabolic processes in skeletal muscle. However, the function and effect of IGF-I depends on the abundance of IGFbinding proteins (IGFBPs), which are responsible for regulating the amount of free IGF-I that is available to its receptors in the tissues, as well as transporting IGF-I in the bloodstream. In intensively managed young bulls slaughtered at 11 months of age, serum IGF-I concentration increased until it reached a plateau at 7-8 months of age which was parallel to maximal concentrate intake (Blanco et al. 2010). In other works comparing older intact bulls and steers, a gradual increase in IGF-I level was observed as sex steroids (i.e. testosterone) increased (mainly from 11 months of age onwards) (Lee et al. 1990) and concomitantly the testicles grew (Schoonmaker et al. 2002). Nevertheless, the afore-mentioned studies were carried out following animal husbandry procedures that involved the use of anabolic steroids both in steers and intact bulls. Collectively, in the previous results serum IGF-I concentration may be increased by gonadal hormones and thus the fact that the steer had been deprived of its endogenous androgen causes a decrease in circulating IGF-I, which is a hormone supporting growth (Lee et al. 1991). Whether an earlier age at castration may have equally modified the endocrine IGF-I pattern in these steers compared to bulls cannot be extrapolated. In any case, plasma level of IGF-I was highly correlated with empty body gain and protein deposition in late-maturing steers (Hayden et al. 1993). 
In this study, plasma testosterone increased in intact bulls from 10 to 11 months of age, but this slight increase was not yet clearly reflected in greater circulating IGF-I, and the main differences in plasma IGF-I between steers and bulls appeared at 19 months of age. We hypothesize that the sustained rise in plasma IGF-I concentration in bulls but not in steers during the last feeding period (from 19 to 21 months of age) might be related to attainment of sexual behavior, suggesting that differences in peripheral IGF-I are due to gonadal rather than nutritional status. Indeed, Vijil et al. (2009) reported that the average age at ejaculate collection for appropriate preparation of semen doses in this breed was around 18 months of age.

Flight speed test may be useful to evaluate the fear response of the calf to being handled by humans (Müller and von Keyserlingk 2006). In this study, differences were observed in flight speed tests between groups, with a tendency for greater speed values in steers than in intact bulls 2 months after castration (11 and 12 months of age) but not at the end of the fattening period (20 months of age). Steers are more temperamental than bulls, even though total mounts per animal are reduced due to castration (Vanderwert et al. 1985). Compared to bulls, steers tend to have higher flight speeds and higher movement in the chute (Bruno 2015). Within each group, flight speed in steers was not associated with their monthly ADG, while flight speed values in bulls were positively associated with growth performance. This is not in agreement with the earlier suggested negative correlation between temperament scores and ADG, although this inverse relationship was deeper in some breeds (Brahman, Hereford, Limousin) than in others (Angus) (Hoppe et al. 2010; Cafe et al. 2011). Therefore, an additional study involving a greater sample size would be required to evaluate in this breed whether less docile animals are more or less productive.

If no septic lesions are found after surgical castration and the calves are kept clean by replenishing their straw bedding daily, behavioral evidence for chronic pain after surgical castration may be limited to small increases in the time spent standing abnormally over the first 2 weeks and small inconsistent increases in lesion licking the month after surgery (Molony et al. 1995). However, Devant et al. (2012) concluded that castration has a lasting reduction on physical activity because young bulls were more active (steps/hour) than steers (castrated at 3 months of age and slaughtered at 10 months).

In this study, even though the flight speed of steers and intact bulls was reduced with the course of the fattening period, the Serrana de Teruel cattle may be classified as a nervous breed when compared to values obtained by Fell et al. (1999), who classified Hereford and Hereford $\times$ Angus calves according to their flight speed values as nervous ( 1.9 to $2.8 \mathrm{~m} / \mathrm{s}$ ) or calm calves ( 0.6 to $1.4 \mathrm{~m} / \mathrm{s}$ ); or by Blanco et al. (2009), who classified as calm the progeny from Parda de Montaña (0.5 to 0.8 $\mathrm{m} / \mathrm{s}$ ) and even Pirenaica breeds $(0.9$ to $1.2 \mathrm{~m} / \mathrm{s})$. In fact, habituation to human handling may be more important than gender to determine cattle temperament. However, in this experiment there was no association between order of entry in the chute and speed values, or between order of entry in the chute and age at test, which confirms the individual variability of the behavioral response in this cattle breed as a possible consequence of their lacking genetic selection.

In conclusion, steers reared until heavy live-weights (21 months of age) grew slowly and had lower plasma IGF-I concentrations than their intact bull counterparts. These differences were mainly highlighted the month after surgery (11 months of age) and the last part of the fattening period (from 19 to 21 months of age). The present results confirm the role of IGF-I as a key anabolic hormone in male beef cattle and thus the measurement of this hormone may reflect growth differences due to altered sex steroids production. After surgical castration (11 and 12 months of age), steers showed a tendency to display greater flight speed values than intact bulls but baseline plasma cortisol concentration did not differ between groups at this time. At the end of the study, steers and bulls reached nearly similar temperament, as flight speed did not differ between them.

\section{ACKNOWLEDGMENTS}

The authors wish to thank the staff of CITA de Aragón and Dr. Jorge Palacio for his valuable advice on flight speed recording. Study supported by the Ministry of Science and Innovation of Spain and the European Union Regional Development Funds (Teruel Investment Funds (FITE 2014-451A) Government of Aragon; INIA PET2007-05-C03-01). J. Álvarez-Rodríguez was in receipt of a grant from INIA-DGA.

\section{REFERENCES}

Albertí P, Panea B, Sañudo C, Olleta JL, Ripoll G, Ertbjerg P, et al. 2008. Live weight, body size and carcass characteristics of young bulls of fiffteen European breeds. Livestock Science 114, 19-30.

Blanco M, Casasús I, Palacio J. 2009. Effect of age at weaning on the physiological stress response and temperament of two beef cattle breeds. Animal 3, 108-117.

Blanco M, Casasús I, Villalba D. 2010. A spline polynomial model to describe serum IGF-I concentration from birth to slaughter in calves: effects of weaning age, pre-weaning concentrate feeding and breed. Domestic Animal Endocrinology 38 , 157-167.

Blanco M, Joy M, Panea B, Albertí P, Ripoll G, Carrasco S, et al. 2012. Effects of the forage content of the winter diet on the growth performance and carcass quality of steers finished on mountain pasture with a barley supplement. Animal Production Science 52, 823-831.

Blanco M, Joy M, Albertí P, Ripoll G, Casasús I. 2014. Performance and carcass quality of forage-fed steers as an alternative to concentrate-based beef production. Italian Journal of Animal Science 13, 864-872. 
Bretschneider G. 2005. Effects of age and method of castration on performance and stress response of beef male cattle: A review. Livestock Production Science 97, 89-100.

Bruno K. 2015. Relationships between behavioural measures and productivity in growing beef cattle. Theses and Dissertations-Animal and Food Sciences, Paper 46. [Cited $01 \quad 08$ 2016] In: http://uknowledge.uky.edu/ animalsci_etds/46.

Burrow HM, Seifert GW, Corbet NJ. 1988. A new technique for measuring temperament in cattle. Proceedings of the Australian Society of Animal Production 17, 154-157.

Cafe LM, Robinson DL, Ferguson DM, McIntyre BL, Geesink GH, Greenwood PL. 201 1. Cattle temperament: Persistence of assessments and associations with productivity, efficiency, carcass and meat quality traits. Journal of Animal Science 89, $1452-1465$.

Cohen RDH, King BD, Thomas LR, Janzen ED. 1990. Efficacy and stress of chemical versus surgical castration of cattle. Canadian Journal of Animal Science 70, 1063-1072.

Decruyenaere V, Buldgen A, Stilmant D. 2009. Factors affecting intake by grazing ruminants and related quantification methods: a review. Biotechnologie, Agronomie, Société et Environnement 13 (4), 559-573.

Devant M, Marti S, Bach A. 2012. Effects of castration on eating pattern and physical activity of Holstein bulls fed highconcentrate rations under commercial conditions. Journal of Animal Science 90, 4505-4513.

Ellenberger MA, Johnson DE, Carstens GE, Hossner KL, Holland MD, Nett TM, et al. 1989. Endocrine and metabolic changes during altered growth rates in beef cattle. Journal of Animal Science 67, 1446-1454.

FAO. 2010. Domestic Animal Diversity Information System, FAO, Rome, Italy; [Cited 1 August 2016]. http://www.fao. org/dad-is/

Fell LR, Colditz IG, Walker KH, Watson DL. 1999. Associations between temperament, performance and immune function in cattle entering a commercial feedlot. Australian Journal of Experimental Agriculture 39, 795-802.

Govoni KE, Hoagland TA, Zinn SA. 2003. The ontogeny of the somatotropic axis in male and female Hereford calves from birth to one year of age. Journal of Animal Science 81, $2811-2817$.

Hayden JM, Williams JE, Collier RJ. 1993. Plasma growth hormone, insulin-like growth factor, insulin, and thyroid hormone association with body protein and fat accretion in steers undergoing compensatory gain after dietary energy restriction. Journal of Animal Science 71, 3327-3338.

Henricks DM, Gimenez T, Gettys TW, Schanbacher BD. 1988. Effects of castration and an anabolic implant on growth and serum hormones in cattle. Animal Production 46, 35-41.

Hoppe S, Brandt HR, König S, Erhardt G, Gauly M. 2010. Temperament traits of beef calves measured under field conditions and their relationships to performance. Journal of Animal Science 88, 1982-1989.

Hunt DW, Henricks DM, Skelley GC, Grimes LW. 1991. Use of trenbolone acetate and estradiol in intact and castratemale cattle: Effects on growth, serum hormones, and carcass characteristics. Journal of Animal Science 69, 2452-2462.

Knight TW, Cosgrove GP, Death AF, Anderson CB. 1999. Effect of method and age at castration on growth rate and meat quality of bulls. New Zealand Journal of Agricultural Research 42, 255-268.

Lee CY, Henricks DM, Skelley GC, Grimes LW. 1990. Growth and hormonal response of intact and castrate male cattle to trenbolone acetate and estradiol. Journal of Animal Science 68, 2682-2689.

Lee CY, Hunt DW, Gray SL, Henricks DM. 1991. Secretory patterns of growth hormone and insulin-like growth factor-I during peripubertal period in intact and castrate male cattle. Domestic Animal Endocrinology 8, 481-489.

Marti S, Velarde A, de la Torre JL, Bach A, Aris A, Serrano A, et al. 2010. Effects of ring castration with local anesthesia and analgesia in Holstein calves at 3 months of age on welfare indicators. Journal of Animal Science 88, 2789-2796.

Marti S, Realini CE, Bach A, Pérez-Juan M, Devant M. 2013. Effect of castration and slaughter age on performance, carcass, and meat quality traits of Holstein calves fed a high-concentrate diet. Journal of Animal Science 91, 1129-1140.

Molony V, Kent JE, Robertson IS, 1995. Assessment of acute and chronic pain after different methods of castration of calves. Applied Animal Behaviour Science 46, 33-48.

Müller R, von Keyserlingk MAG. 2006. Consistency of flight speed and its correlation to productivity and to personality in Bos taurus beef cattle. Applied Animal Behaviour Science 99, 193-204.

Pang WY, Earley B, Sweeney T, Crowe MA. 2006. Effect of carprofen administration during banding or Burdizzo castration of bulls on plasma cortisol, in vitro interferon- $\gamma$ production, acute-phase proteins, feed intake, and growth. Journal of Animal Science 84, 351-359.

Ripoll G, Albertí P, Álvarez-Rodríguez J, Blasco I, Sanz A. 2016. Body size, carcass and meat quality of three commercial beef categories of 'Serrana de Teruel' breed. Spanish Journal of Agricultural Research 14 (3) e0604, doi:10.5424/sjar/20161439122

Schoonmaker JP, Loerch SC, Fluharty FL, Turner TB, Moeller SJ, Rossi JE, et al. 2002. Effect of an accelerated finishing program on performance, carcass characteristics, and circulating insulin-like growth factor I concentration of early-weaned bulls and steers. Journal of Animal Science 80, 900-910.

Stafford KJ, Mellor DJ, Todd SE, Bruce RA, Ward RN. 2002. Effects of local anaesthesia or local anaesthesia plus a nonsteroidal anti-inflammatory drug on the acute cortisol response of calves to five different methods of castration. Research in Veterinary Science 73, 61-70.

Ting STL, Earley B, Hughes JML, Crowe MA. 2003. Effect of ketoprofen, lidocaine local anesthesia, and combined xylazine and lidocaine caudal epidural anesthesia during castration of beef cattle on stress responses, immunity, growth, and behavior. Journal of Animal Science 81, $1281-1293$

Vanderwert W, Berger LL, McKetith FK, Baker AM, Gonyou HW, Bechtel PJ. 1985. Influence of zeranol implants in growth, behavior and carcass traits in Angus and Limousin bulls and steers. Journal of Animal Science 61, 310-319.

Vijil E, Picot A, Hernández M, Pastor F, Quintín FJ, Sevilla E, et al. 2009. Raza bovina Serrana de Teruel. Estructura poblacional, características reproductivas y maternales. Archivos de Zootecnia 58 (Suppl. 1), 509-512. 


\section{Author Query Form}

\section{Journal: Animal Science Journal}

\section{Article: asj_12728}

Dear Author,

During the copyediting of your paper, the following queries arose. Please respond to these by annotating your proofs with the necessary changes/additions.

- If you intend to annotate your proof electronically, please refer to the E-annotation guidelines.

- If you intend to annotate your proof by means of hard-copy mark-up, please use the standard proofing marks. If manually writing corrections on your proof and returning it by fax, do not write too close to the edge of the paper. Please remember that illegible mark-ups may delay publication.

Whether you opt for hard-copy or electronic annotation of your proofs, we recommend that you provide additional clarification of answers to queries by entering your answers on the query sheet, in addition to the text mark-up.

\begin{tabular}{|c|l|l|}
\hline Query No. & \multicolumn{1}{|c|}{ Query } & \multicolumn{1}{|c|}{ Remark } \\
\hline Q1 & $\begin{array}{l}\text { AUTHOR: Please provide a short version of the article title (maximum of "40" } \\
\text { characters - spaces included) to be used as running header on top. }\end{array}$ \\
\hline Q2 & $\begin{array}{l}\text { AUTHOR: Please confirm that given names (red) and surnames/family names } \\
\text { (green) have been identified correctly. }\end{array}$ \\
\hline
\end{tabular}




\section{WI LEY \\ Online Proofing System}

1. Corrections should be marked with the Adobe Annotation \& Comment Tools below:

http://wiley-black...qTrJcH\&user=author +

1) wiley-blackwell.spi-global.com/authorproofs/journal/onlineproofs/index2.php?id=vOgLEv/sdvuzhoT03112014205007IVpecDjWzqTrJcH\&user=author

2. To save your proof corrections, click the 'Publish Comments' button. Publishing your comments saves the marked up version of your proof to a centralized location in Wiley's Online Proofing System. Corrections don't have to be marked in one sitting - you can publish corrections and log back in at a later time to add more.

3. When your proof review is complete we recommend you download a copy of your annotated proof for reference in any future correspondence concerning the article before publication. You can do this by clicking on the icon to the right of the 'Publish Comments' button and selecting 'Save as Archive Copy...'.

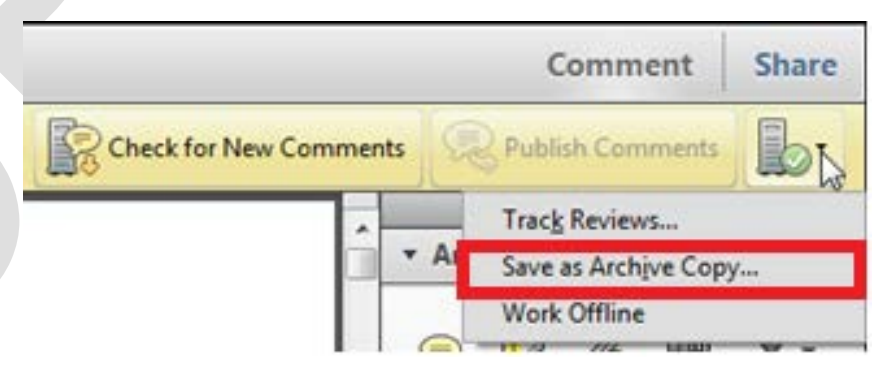

4. When your proof review is complete and you are ready to send corrections to the publisher click the 'Complete Proof Review' button that appears above the proof in your web browser window. Do not click the 'Complete Proof Review' button without replying to any author queries found on the last page of your COMPLETE PROOF REVIEW proof. Incomplete proof reviews will cause a delay in publication. Note: Once you click 'Complete Proof Review' you will not be able to mark any further comments or corrections.

\section{Firefox, Chrome, Safari Users}

If your PDF article proof opens in any PDF viewer other than Adobe Reader or Adobe Acrobat, you will not be able to mark corrections and query responses, nor save them. To mark and save corrections, please follow these instructions to disable the built-in browser PDF viewers in Firefox, Chrome, and Safari so the PDF article proof opens in Adobe within a Firefox, Chrome, or Safari browser window. 